\title{
СТРАТЕГІЧНЕ БАЧЕННЯ НОВОЇ МОДЕЛІ ВИЩОЇ ОСВІТИ: РУХ ДО СТВОРЕННЯ УНІВЕРСИТЕТІВ СВІТОВОГО КЛАСУ
}

\author{
Наукова доповідь на методологічному семінарі НАПН України \\ "Шляхи і механізми підвищення конкурентоспроможності \\ університетів України» 19 листопада 2020 р. \\ https://doi.org/10.37472/2707-305X-2020-2-2-13-7
}

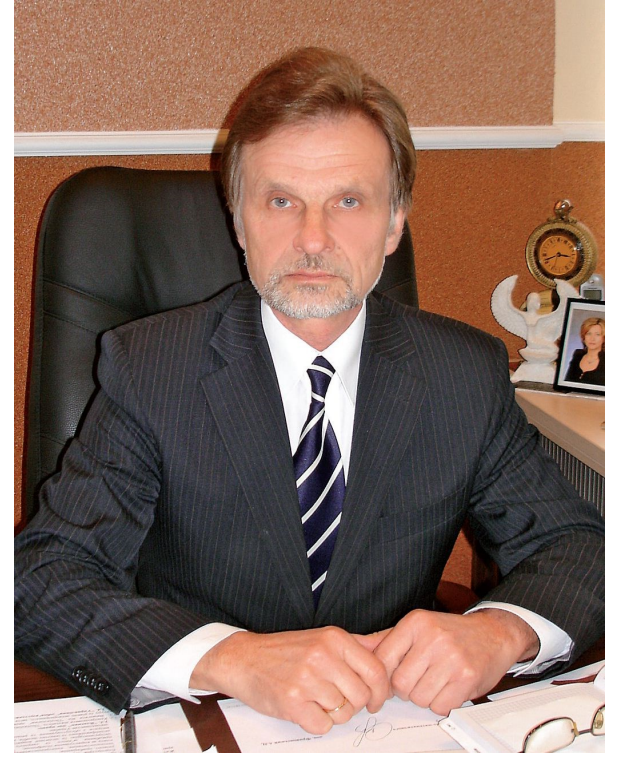

САУХ Петро Юрійович

доктор фрілософських наук, профресор, дійсний член (академік) НАПН України, академік-секретар Відділення вищої освіти Начіональної академії педагогічних наук України, м. Київ, Україна

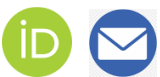

Анотація. На основі системного аналізу ролі та значення вищої освіти в умовах інноваційного суспільства визначено основні "больові точки», пов'язані із втратою закладами вищої освіти їх традиційної історичної місії. Окреслено стратегічне бачення нової моделі вищої освіти, яка відповідала б вимогам економіки четвертої «цифрової» революиії (Industry 4.0). Запропоновано та обгрунтовано три конкретні кроки на шляху модернізації інституційної структури освітньої системи в технонауковому контурі суспільства знань. Сорормульовано алгоритм ідеї університету світового класу та визначено шляхи його реалізації у дискурсі вітчизняних реалій і можливостей.

Ключові слова: вища освіта; уніфрікація; глобалізація; біфуркація; освітньо-промислова група; когнітивний дисонанс; культурноцивілізаційна самоідентифікація; університет світового класу.

Вища освіта має визначальне значення для успішного розвитку будь-якої країни. Її стан, ефективність функціонування, значущість у суспільстві є показниками розвитку держави. Революційні зміни технологій, які грунтуються на інтелектуальних ресурсах високого рівня, і пов'язана з цим конкуренція провідних країн світу за ці ресурси стають архіважливими чинниками, що визначають не лише рівень розвитку економіки, а й соціокультурне і політичне життя суспільства у XXI столітті. У зв'язку з цим відбувається системна реструктуризація вищої освіти, що має максимально наблизитись до вимог інноваційного суспільства. Поступово змінюють свій образ класичні університети. Абсолютна більшість зарубіжних і вітчизняних учених зазначає, що нинішня система вищої освіти не відповідає вимогам часу. Її критикують і моделюють новий образ, адекватний сучасній соціокультурній ситуації. Але й ці некласичні обриси архітектоніки освіти не завжди вселяють надію, що ми на правильному шляху. Як результат, багатьох учасників освітнього процесу не полишає відчуття когнітивного дисонансу як при спробі оцінити істинний стан академічного середовища, так і при спробі дати оцінку запропонованим «рецептам».

1. Вища освіта: від когнітивного дисонансу до алгоритму майбутнього ренесансу

Умови існування людства в третьому тисячолітті вимагають негайного переходу до нової стратегії розвитку суспільства на 
основі широкомасштабного використання знань та інформації як стратегічного ресурсу, а також перспективних високоефективних технологій як інструментів. Система вищої освіти сприймається за цих умов не лише найважливішим чинником технологічного й соціального поступу тієї чи іншої країни, а стратегічним фактором виживання цивілізації та подолання ії глобальної кризи. Усе це радикально трансформує образ вищої освіти, виводить ії за межі традиційної історичної місії. Масштаби цих змін є настільки радикальними, що зумовлюють у світовій академічній спільноті не лише песимістичні прогнози щодо «банкрутства» історичної місії університетів (В. Браун, Ж. Дерріда, П. Друкер, Ж. Ліотар), а й розгубленість перед обрисами постмодерної вищої освіти (Дж. Міллікен, Б. Рідінгс, М. Фуко) (Collini, 2011; Ридигинс, 2009; Никольский, 2010). Багато хто із відомих педагогів-теоретиків висловлює думку, що через якихось 20-30 років великі центри вищої освіти, прославлені університети можуть стати реліквією, а то й, імовірно, припинять своє існування як незалежні інститути і співтовариства вчених. Передбачається, що цей «оплот зарозумілості й успішних поколінь» у минулому сьогодні не витримає конкуренції з вузькопрофільними навчальними закладами, зорієнтованими на прагматику конкретних технологій, яких вимагає економіка четвертої «цифрової» революції (Industry 4.0). Не без підстав професор культурології Манчестерського університету Террі Іглтон, охарактеризувавши неоліберальний контекст освітніх реформ на Заході, говорить про «повільну смерть університету» (Иглтон, 2015).

Незважаючи на певне перебільшення цих прогнозів, частка істини і причини для занепокоєння у них є. По-перше, нині дійсно спостерігається тенденція інкорпорування ідеалів ринку і в навчальний процес, і в організацію наукової роботи, яка примушує університет жити не за логікою соціального інституту, а за логікою виробництва. Тектонічні зсуви в науці, яка стає технонауковим конвеєром, зорієнтованим на ринок, руйнують усталені наукові університетські традиції. Схоже, що високий рівень комерціалізації університетів $€$ незворотним. По-друге, відбувається диверсифікація вищої освіти, яка виходить за межі класичних, концептуальних, інституціональних і географічних кордонів. На «ринку вищої освіти» з'являються нові заклади освіти (віртуальні, франчайзингові, корпоративні університети), зорієнтовані, насамперед, на прагматику конкретних технологій.
Вони не лише формують «агресивне конкурентне середовище», а й посилюють процеси «масовізації» університетської освіти, яка (за усіх її позитивів) загрожує руйнуванням класичної елітарної освіти. По-третє, прагнення традиційних університетів до економічної гнучкості та намагання вписатися у глобалізаційні процеси інтернаціоналізації й уніфікації освіти спричиняють «кризу їх національно-культурної ідентифікації». Історично вибудовуючи свою ідентичність з огляду на потреби держави, сьогодні університети змушені надавати послуги, не прив'язані до їх місцезнаходження. Їхні послуги перетворюються на товар для індивідуального споживання, який можна реалізовувати як у будь-якій країні, так і у віртуальному просторі.

Якою має бути реакція вищої школи на ці процеси, як свідчить Римське Комюніке Міністрів (Rome Ministerial Communique, 2020), відповідальних за вищу освіту у Європейському просторі, достеменно ніхто не знає. Зрозуміло одне - як би ми не розцінювали їх, скільки 6 не дискутувати й не «пускали сльозу» щодо обмеженості постмодерної освіти, яка «ігнорує усталені смисловизначальні цінності» людського життя і зводить до мінімуму можливості соціокультурного оновлення людини, не помічати цих радикальних змін або, тим паче, протистояти їм було $б$ абсурдно (Саух, 2017). Залишати незмінною традиційну класичну університетську освіту, продовжувати випускати фахівців, які глибоко розуміють буття, його фундаментальні закони, світоглядно обізнані та гуманістично виховані, але мало здатні виконувати інноваційні соціально-професійні ролі, рівноцінно самогубству. Навпаки, нинішня ситуація вимагає дієвої реакції традиційної вищої освіти, яка має розумно поєднати утилітарну прагматику професійної підготовки фахівця з «прагматикою» фундаментальних знань, завдяки яким інноваційне суспільство забезпечить потреби цивілізаційного розвитку, збереже і посилить його гуманісти чний потенціал, наповнить життя і діяльність сми слами та цінностями. Це дасть змогу класичній вищій освіті не лише зберегти себе, а й надалі виконувати важливу соціокультурну місію, приречену виводити нові покоління у сучасний глобалізований світ професіоналами і гармонійно розви неними людьми, здатними нести відповідальність за свої дії. Сьогодні важко знайти людину, яка заперечувала б, що роль освіти у сучасному суспільстві зводиться не лише до передачі знань і соціального досвіду із покоління в покоління. її 
місія полягає у тому, щоб готувати фахівця до діяльності в умовах біфуркації й невизначеності, сприяючи виходу із можливих глобальних криз і катастроф. Адже подолати їх можна не на основі застарілих, а лише грунтуючись на випереджувальних знаннях і діях. Ось чому виникає потреба в такій моделі вищої освіти, яка принципово змінює старі функції на випередження та орієнтацію на майбутнє.

2. Стратегічне бачення нової моделі вітчизняної вищої освіти

Незважаючи на те, що саме вища освіта була за усі роки незалежності України об'єктом чи не найбільшої кількості реформаторських ініціатив, серед яких: вступ до Болонського процесу; запровадження зовнішнього незалежного оцінювання при вступі до закладів вищої освіти; спроби оптимізації системи 3ВО; трансформація моделі їх фінансування; прийняття Закону України «Про вищу освіту», реалізація Стратегії реформування вищої освіти в Україні до 2020 р., підготовленої за підтримки USAID (2015), та розроблення проєкту нової Стратегії розвитку вищої освіти до 2031 р. (2020), тощо - якісні зміни ледь помітні. Невипадково розбіжність між суспільними очікуваннями й результатами продовжує зростати й призводить до дедалі більшого незадоволення й недовіри. Спробам реформування вищої освіти весь час бракувало й бракує системності, у програмах і гаслах суб'єктів освітньої політики нерідко є елементи популізму, часто висуваються нереалістичні завдання. Як наслідок, після намагань реформувати вищу освіту в контексті нинішніх викликів, пов'язаних з появою та швидким розвитком нових технологій, комерціалізацією, посиленням глобальної конкуренції, наслідками пандемії коронавірусу тощо, в академічному середовищі знову відбувається обговорення майбутнього вищої освіти в Україні. Одні переконують, що нам достатньо "косметичного ремонту» існуючої системи, інші пропонують «зруйнувати ії під корінь» і створити якісно нову модель вищої освіти. Але водночас із поширеною i, на нашу думку, обґрунтованою категоричністю, існує пропозиція поступової, системної і глибокої трансформації вищої освіти та українських університетів. Це означає, що коли йдеться сьогодні по нову модель вищої освіти й переслідується мета підвищення конкурентоспроможності українських університетів, слід враховувати принаймні чотири ванливих фоктори:

- велику інерційність системи освіти;
- рівень розвитку нашої економіки;

- законодавчі обмеження;

- фінансові обмеження на цьому етапі.

Тобто будь-які ідеї щодо реформування, трансформації та «перевинайдення» університетів та вищої освіти загалом мають базуватися на реальних можливостях і давати відповіді на наявні виклики. Ми, як свідчить практика, навчилися створювати, так би мовити, «ідеальні моделі». Можливо це й добре. Але ми маємо розуміти, що вони можуть бути лише певним орієнтиром і мають доповнюватися більш реалістичними, не «ідеальними», а наближеними до реалій нашого життя моделями. Такі моделі дають змогу рухатися уперед можливо не так швидко, але більш стабільно із розумінням послідовності дій і значно меншими ризиками.

Слід раз і назавжди усвідомити, що український університет, уподібнюючись до сучасних європейських, північноамериканських, японських, китайських має залишатися українським. Тим паче, апелюючи до університетів світового класу різних країн, легко помітити, що якогось одного оптимального чи «золотого» шляху до успіху не існує й не може існувати в принципі. Далеко не усе з їх досвіду потрібно запозичувати. Не все буде працювати в наших умовах. Крім того, в умовах глобальної конкуренції ці університети не стоять на місці. Тому «копіювання», на яке ми часто спрямовані, має ризик запозичити те, від чого ці «світові зразки» вже сьогодні готові відмовитися.

ґрунтуючись на сучасному стані української системи вищої освіти та враховуючи процеси її «масовізації», відірваності від життя й галузевої розпорошеності, чи не найважливішими у дискурсі модернізованої моделі будуть кілька важливих кроків.

Перший крок - провести детальні інвентаризацію та оптимізацію мережі закладів вищої освіти. Оптимізувати ЗВО можна шляхом консолідації, об'єднання, укрупнення на основі спеціальної державної цільової програми. Й не лише тому, що у нас багато закладів вищої освіти (це не така вже й велика біда), а тому, що в Україні мало потужних університетів, які були б конкурентоспроможними у світовому освітньому просторі.

Другий крок - запровадити практику створення освітньо-промислових груп (ЗВО і підприємств), які об'єднували б свої матеріальні й нематеріальні активи для реалізації інвестиційних та інших проєктів і програм, спрямованих на підвищення якості підготовки фахівців і поліпшення 
матеріально-технічної бази й інфраструктури. Окремі галузеві освітньо-промислові групи могли 6 включати, окрім 3ВО, заклади професійної (професійно-технічної) освіти, ліцеї, коледжі, комплексні курси перепідготовки фахівців тощо. Усе це сприяло 6 розширенню практики соціального партнерства 3 ВО з компаніями-роботодавцями, залученню їх до розроблення навчальних програм, розвитку soft skills студентів через реалізацію відповідних програм, залученню представників компаній і бізнесу до проведення занять (читання лекцій, проведення майстеркласів тощо), запровадженню програм стажування професорсько-викладацького персоналу в компаніях для набуття (удосконалення) практичного досвіду.

Третій крок - привести структуру вищої школи у відповідність до Міжнародної стандартної класифікації освіти (ISCED 2011), тобто диференціювати за видами згідно з рівнями і типами («А» - для подальшої освіти і висококваліфікованої праці, «Б» - для ринку праці). Використовуючи досвід європейських країн, заклади вищої освіти доцільно було б поділити на три види: дослідницькі університети (швидше за все - окремо класичні й політехнічні університети); університети прикладних наук (ЗВО широкого профілю) й вузькоспеціалізовані вищі школи (наприклад, мистецькі 3ВО). Важливо було б подібну класифікацію закріпити на рівні нашого законодавства.

Метою цих значущих кроків має бути одне перетворення вітчизняних закладів вищої освіти на провідні центри інтелектуальної підтримки і наукового забезпечення соціального й економічного розвитку на секторальному, регіональному, державному та глобальному рівнях. Окрім цього, стратегія розвитку системи вищої освіти в Україні має передбачати не лише культивування, а й реалізацію ідеї університету світового класу в короткостроковій перспективі, який $€$ сьогодні найбільш яскравим прикладом конкурентоспроможності закладів вищої освіти на міжнародному рівні.

3. Алгоритм ідеї університету світового класу та шляхи його реалізації

Ідея «університету світового класу» стала в наш час особливо привабливим трендом, який не просто означає покращення якості освіти й наукових досліджень, а й, що більш важливо, розвиток спроможності конкурувати на глобальному ринку освітніх послуг, завдячуючи набуттю, культивуванню й продукуванню передових і проривних знань. Наприклад, Джаміл Салмі в роботі
«Створення університетів світового класу», здійснивши компаративний аналіз топових зарубіжних університетів, доходить висновку, що в основі їх діяльності закладено три основні фактори, які тісно взаємопов'язані й доповнюють один одного. Зокрема, це:

- висока концентрація талантів (викладачів і студентів), висока репутація випускників;

- ресурси для створення сприятливих умов навчання й проведення випереджувальних наукових досліджень;

- ефективність менеджменту, який сприяє розвиткові стратегічного бачення, інноваціям і гнучкості, що дає змогу ухвалювати рішення й керувати ресурсами без бюрократичних перепон (Салми, 2009).

Щоб реалізувати ідею створення університету світового класу, слід враховувати дві обставини. Перша має зовнішній характер і пов'язана із державною ініціативою та зацікавленістю на національному й регіональному рівнях. Друга обставина - внутрішня, тобто реалізація можливостей самих університетів. У минулому роль держави у формуванні університету світового класу не була вирішальним фактором. Історія університетів, що належать до Ліги Плюща у США, свідчить, що вони досягли видатних успіхів у результаті збільшення власних ресурсів без втручання держави. Оксфорд і Кембридж віками удосконалювалися самостійно. Сьогодні малоймовірно очікувати, що університет світового класу може бути створеним без сприяння суспільства і без підтримки держави.

Міжнародний досвід дає змогу зробити висновок, що нині практикуються три основні стратегії, які сприяють створенню університетів світового класу.

Перша. На державному рівні відбираються кілька університетів, які мають відповідний потенціал для перетворення їх у знакові, надаючи їм істотну організаційну й фінансову підтримку.

Друга. Стимулювання існуючих університетів до злиття й трансформації у потужні 3ВО, які могли 6 забезпечити рух до університету світового класу.

Третя. Створення університетів світового класу, так би мовити, з нуля.

Перевагою першої стратегії $€$ те, що вона вимагає значно менших витрат, ніж організація нових університетів з нуля. Цим шляхом пішла Німеччина виділивши 10 найпотужніших університетів і створивши фінансові й нормативні умови, які допоможуть їм конкурувати на міжнародному ринку. Друга стратегія, згідно з якою діють 
такі країни, як Франція і Данія, має свої переваги. Але злиття університетів нерідко пов'язане із ризиком загострити проблеми, а не розв'язати їх. Створення єдиної академічної культури і єдиного бачення майбутнього в процесі оптимізації системи ЗВО часто виявляється непростим завданням. Щодо третьої стратегії, то цим шляхом мають змогу йти надзвичайно заможні країни. Адже створення нового університету з нуля вартує щонайменше 500 млн доларів.

Для України, враховуючи невдалий досвід злиття університетів, найбільш конструктивною могла 6 стати перша стратегія: виокремлення 710 найбільш потужних університетів, забезпечивши їх багатосторонньою державною підтримкою. Хоча нехтувати другим варіантом теж не слід. Очевидно, що принаймні п'ять українських університетів уже сьогодні можуть претендувати на включення у топ-групу глобальних університетських рейтингів. Але значно більше університетів здатні бути успішними в дисциплінарних глобальних рейтингах. Тому стратегія створення університетів світового класу може бути успішнішою, якщо її доповнити низкою топових університетів за окремими напрямами науково-технологічного розвитку.

у будь-якому разі підвищення конкурентоспроможності університетів України - важливе державне завдання. Чи здатна держава продемонструвати свою конкурентоспроможність на глобальному ринку освіти й науки, є питанням національної безпеки. Без сучасної, розвиненої конкурентоспроможної системи освіти, зокрема вищої, неможливо досягнути високого рівня добробуту народу, зберегти та підтримати свою культурну і національну ідентичність.

\section{СПИСОК ВИКОРИСТАНИХ ДЖЕРЕЛ}

Європейська Комісія. (2017). Заключний звіт незалежного європейського аудиту національної системи досліджень та інновачій України. Інструмент політичної підтримки програми «Горизонт 2020». Короткий зміст та рекомендації щодо покращення секторальної політики. http:// h2020.com.ua/wp-content/uploads/2017/03/KI-AX16-008-UK-N-Transl.pdf

Закон України "Про вищу освіту». (2014, 1 липня). https://zakon.rada.gov.ua/laws/show/1556-18

Иглтон, Т. (2015). Медленная смерть университета. http://istorja.ru/blogs/entry/45-terri-igltonmedlennaya-smert-universiteta/

Міністерство освіти і науки України. (2015). Стратегія ресормування вищої освіти в Україні до 2020 р. https://bit.ly/37pdXSh
Міністерство освіти і науки України. (2020, 25 вересня). МОН пропонує для громадського обговорення проєкт Стратегії розвитку вищої освіти України. https://bit.ly/2KIGvCV

Никольский, В.С. (2010). Коммодификация знания в системе высшего образования: эссе о ценностях. высшее образование в России, (3), 149-152.

Ридингс, Б. (2009). Университет в руинах. Минск.

Салми, Дж. (2009). Создание университетов мирового класса. Москва: «Весь Мир».

Салми, Дж. (2016). Работают ли инициативы академического превосходства по созданию университетов мирового класса? Международное высшее образование, (87), 23-24. https://www.hse.ru/ data/2016/11/16/1110215904/WHE_14_view.pdf

Саух, П.Ю. (2012). Сучасна освіта: портрет без прикрас : монографія. Житомир: Видавництво ЖДУ ім. І. Франка.

Cаух, П.Ю. (2017). Вища освіта в очікуванні майбутнього ренесансу: Проблеми і перспективи. Український контекст. In Наукове забезпечення розвитку освіти в Україні: актуальні проблеми теорії $і$ практики (до 25-річчя НАПН України) (с. 329-330). Київ: Видавничий дім «Сам». http://naps.gov.ua/ua/ activities/publications/

Худзик, Дж. К. (2016). Интеграция интернационализации XXI века в институциональное управление и университетское лидерство. Международное высmее образование, (83), 10-12. https://www.hse.ru/ data/2016/01/21/1137869301/WHE_10_view.pdf

Altbach, P. (2003). The Costs and Benefits of World-Class Universities. International Higher Education, (33). https://doi.org/10.6017/ihe.2003.33.7381

Collini, S. (2011). From Robbins to McKinsey: The Dismantling of the Universities. London Review of Books, 33 (16). https://www.Irb.co.uk/the-paper/v33/n16/ stefan-collini/from-robbins-to-mckinsey

Hazelkorn, E. (2017). What does global higher education mean for university leaders. Leadership Foundation for Higher Education. https://arrow.tudublin.ie/ cserrep/63/

Kharas, H. (2017). The unprecedented expansion of the global middle class: An update. Brookings India. http://hdl.handle.net/11540/7251

European Commission. (2012). Communication from the Commission to the European Parliament, the Council, the European Economic and Social Committee and the Committee of the Regions. Rethinking Education: Investing in skills for better socio-economic outcomes. https://eur-lex.europa.eu/legal-content/EN/TXT/? uri=CELEX\%3A52012DC0669

International Standard Classification of Education. ISCED 2011 (2012). UNESCO Institute for Statistics. http:// uis.unesco.org/sites/default/files/documents/ international-standard-classification-of-educationisced-2011-en.pdf

Rome Ministerial Communique. (2020, 19 November). https://www.bmbf.de/files/ BFUG_Final_Draft_Rome_Communique-link.pdf

Weizsaecker, E., \& Wijkman, A. (2018). Come on! Capitalism, Short-termism, Population and the Destruction of the Planet. New York: Springer. https:// doi.org/10.1007/978-1-4939-7419-1 


\section{STRATEGIC VISION OF A NEW MODEL OF HIGHER EDUCATION: \\ MOVEMENT TO CREATE WORLD-CLASS UNIVERSITIES}

Scientific report at the methodological seminar of the National Academy of Educational Sciences of Ukraine "Ways and Mechanisms of Increasing the Competitiveness of Universities", November 19, 2020

\section{Petro Saukh}

DSc in Philosophy, Professor, Full Member (Academician) of NAES of Ukraine, Academician Secretary of the Division of Higher Education, National Academy of Educational Sciences of Ukraine, Kyiv, Ukraine

Abstract. The main "pain points" associated with the loss by higher education institutions of their traditional historical mission are identified based on the system analysis of the role and importance of higher education in an innovative society. The strategic vision of a new model of higher education that would meet the Industry 4.0 requirements is outlined. Three concrete steps towards modernizing the educational system's institutional structure in the knowledge society techno-scientific circuit are proposed and grounded. The algorism of the idea of a world-class university is defined; the ways of its realization in the discourse of domestic realities ad opportunities are identified.

Keywords: higher education; unification; globalization; bifurcation; educational and industrial group; cognitive dissonance; cultural and civilization self-identification; world-class university.

Дата публікації: 18 грудня 2020 р. 